\section{G434(P) FAMILIAL DIABETES MELLITUS: 2 SIDES OF A COIN}

P Vasista, P Sundaram. Paediatrics, Leicester Royal Infirmary, UHL NHS Trust, Leicester, UK

\subsection{6/archdischild-2020-rcpch.375}

Aim To understand the difference in presentation of an inherited condition depending on the mode of inheritance.

Case Report Case A: 11 years old girl with history of tiredness, normal BMI, had high blood glucose BG $(7.1 \mathrm{mmol} / \mathrm{L})$ and $\mathrm{HbA} 1 \mathrm{c}(45 \mathrm{mmol} / \mathrm{mol})$. There was family history of Type 2 Diabetes mellitus (DM) in mother, diagnosed at age of 23 years.

Oral glucose tolerance test:

\begin{tabular}{ll}
\hline & BG (mmol/L) \\
\hline $0 \min$ & 6.2 \\
$60 \mathrm{~min}$ & 9.8 \\
$120 \mathrm{~min}$ & 8.0 \\
\hline
\end{tabular}

\begin{tabular}{ll}
\hline HbA1c & $45 \mathrm{mmol} / \mathrm{mol}$ \\
\hline C- peptide & $616(298-2350 \mathrm{pmol} / \mathrm{l})$ \\
Insulin & $10.3(4.4-26 \mathrm{mlU} / \mathrm{l})$ \\
Insulin antibodies & $<2 \mathrm{mg} / \mathrm{L}$ \\
Islet cell antibody & Negative \\
Anti GAD antibody & $<5 \mathrm{IU} / \mathrm{ml}$ \\
\hline
\end{tabular}

\begin{tabular}{ll}
\hline Blood Glucose (BG) & $19 \mathrm{mmol} / \mathrm{l}$ \\
\hline Insulin & $<2 \mathrm{mlU} / \mathrm{L}(4.4-26)$ \\
C- peptide & $42 \mathrm{pmol} / \mathrm{L}(298-2350)$ \\
IA2 antibody & $<10 \mathrm{IU} / \mathrm{ml}(0-10)$ \\
Anti GAD antibody & $<5 \mathrm{U} / \mathrm{ml}(0-10)$ \\
Islet cell antibody & Negative \\
Thyroid function test & Normal \\
\hline
\end{tabular}

Genetic test confirmed MODY - Heterozygous GCK mutation. She did not require any treatment and had stable $\mathrm{HbA1c}$ on further regular monitoring.Case $B-10$ days old term female baby, weighing $1.88 \mathrm{Kg}(<0.4$ th centiles), admitted in hospital for jaundice, was found to have glycosuria and hyperglycaemia $(\mathrm{BG}=24 \mathrm{mmol} / \mathrm{L})$. Her mother had gestational Diabetes and father had type 2 DM.

Genetic test confirmed MODY - Homozygous GCK mutation. She was managed with IV fluids and intravenous insulin infusion and then started on sensor augmented insulin pump.

Conclusion MODY GCK mutation accounts for $\sim 15 \%$ of the familial DM. Glucokinase acts as 'glucose sensor' for secretion of insulin in pancreas. Mutation of GCK gene results in 'resetting' of the glucose sensors, causing delayed secretion of insulin.

The manifestation of symptoms varies with type of mutation in GCK-MODY. The commoner heterozygous mutation is asymptomatic with stable mild hyperglycaemia and no treatment is required. The rarer homozygous mutation presents as permanent neonatal DM requiring life-long insulin therapy.

\section{G435(P) HYPERTENSION IN CHILDREN WITH DIABETES}

${ }^{1}$ AH Hatata, ${ }^{2}$ MA Tasbihi, ${ }^{2}$ RO Misquith. ${ }^{1}$ Paediatric Ward, Bedford Hospital NHS Trust, Bedford, UK; ${ }^{2}$ Paediatric Ward, Luton and Dunstable University Hospital, Luton, UK

\subsection{6/archdischild-2020-rcpch.376}

Aim To Monitor the persistance of abnormal blood pressure recordings in young age diabetes patients.

Method The data was collected from a Paediatric diabetes unit of a DGH for national Paediatric diabetes audit for the year 2017 - 18. There were 106 children in the age group of 12 - 18 years. We classified any blood pressure reading above the 95th centile for the age, sex and height as hypertension.

Results There were 27(25.4\%) patients out of 106 who had at least one blood pressure reading above the 95th centile. 16 were male and 11 females (table 1, 2 and 3).

\section{Abstract G435(P) Table 1 Ethnic origin}

\begin{tabular}{ll}
\hline Ethnic origin & Numbers \\
\hline White British & 15 \\
Asian Pakistani & 4 \\
Black African & 2 \\
Asian Bangladeshi & 1 \\
Asian Other & 1 \\
Any white & 1 \\
Mixed white and black African & 1 \\
Mixed white and black Caribbean & 1 \\
Not tested & 1
\end{tabular}

\section{Abstract G435(P) Table 2 BMI}

\begin{tabular}{lll}
\hline Category & BMI centiles & Numbers \\
\hline Obese & $>98$ th & 5 \\
Overweight & $91-98$ & 5 \\
Normal weight & $2-91$ & 15 \\
Underweight & $<2$ & 2 \\
\hline
\end{tabular}

Abstract G435(P) Table 3 Blood pressure readings

\begin{tabular}{llllll}
\hline $\begin{array}{l}\text { Number BP } \\
\text { reading }\end{array}$ & $\begin{array}{l}\text { No. of } \\
\text { patients }\end{array}$ & $\begin{array}{l}4 \text { abnormal } \\
\text { readings }\end{array}$ & $\begin{array}{l}3 \text { abnormal } \\
\text { readings }\end{array}$ & $\begin{array}{l}2 \text { abnormal } \\
\text { readings }\end{array}$ & $\begin{array}{l}1 \text { abnormal } \\
\text { reading }\end{array}$ \\
\hline 4 & 7 & 0 & 1 & 0 & 6 \\
3 & 8 & - & 1 & 0 & 7 \\
2 & 7 & - & - & 2 & 5 \\
1 & 5 & - & - & - & 5 \\
\hline
\end{tabular}

23 out of 27 patients (85\%) had only one abnormally high BP, $2(7.4 \%)$ had 2 readings and $2(7.4 \%)$ had 3 abnormally high BP.

Conclusion Majority of children with hypertention had only one abnormal reading, only with $15 \%$ of the patients a high blood pressure was recorded more than once. 